Egyptian Journal of Aquatic Biology \& Fisheries

Zoology Department, Faculty of Science,

Ain Shams University, Cairo, Egypt.

ISSN $1110-6131$

Vol. 24(2): 177 - 194 (2020)

www.ejabf.journals.ekb.eg

\title{
Accumulation of chromium in Lemna minor under the effect of pH and EDTA variation and assessment of the treatment impact on the Nile tilapia
}

\section{(Oreochromis niloticus)}

\author{
Hassnaa A. Saleh ${ }^{1}$ and Reda M. El- Shahat ${ }^{2}$ \\ 1- Department of Environmental Research and Medical Malacology, Theodor Bilharz Research \\ Institute (TBRI), P.O. Box 30, Imbaba, Giza, Egypt. \\ 2- Department of Agricultural Microbial, Soils \& Water and Environment Research Institute \\ (SWERI), Agricultural Research Center (ARC), P.O. Box 175 , El- Orman, Giza, Egypt. \\ *Corresponding Author: a_hassnaa@yahoo.com
}

\begin{abstract}
ARTICLE INFO
Article History:

Received: Feb. 8, 2020

Accepted: March 22, 2020

Online: March 28, 2020
\end{abstract}

Keywords:

Nile tilapia

Oreochromis niloticus

Chromium

Lemna minor

Accumulation

EDTA

\begin{abstract}
Water pollution with chromium $(\mathrm{Cr})$ is a major threat to the environment and human health. Therefore this study was conducted to evaluate the efficiency of aquatic plant Lemna minor as a natural biological tool in the accumulation of $\mathrm{Cr}$ from polluted water under the effect of $\mathrm{pH}$ and Ethylene Diamine Tetra Acetic Acid (EDTA) and assess the impact of this treatment on the growth of Nile tilapia. L. minor fronds were exposed to different concentrations of $\mathrm{Cr}(0,2$, 4, 6, 8 and $\left.10 \mathrm{mg} \mathrm{L}^{-1}\right)$ with $\mathrm{pH}(5,6,7,8$ and 9) for periods of 5, 10, 15 and 20 days. The highest accumulation of $\mathrm{Cr}$ was $\left(9563.81 \pm 222.47 \mu \mathrm{g} \mathrm{g}^{-1}\right.$ dry wt) at 10 $\mathrm{mg} \mathrm{L}^{-1}$ with $\mathrm{pH} 5$ after 10 days of treatment. While in the groups that enriched with EDTA $(25,50,75$ and $100 \mu \mathrm{M})$ for periods of 5, 10, 15 and 20 days, maximum accumulation of $\mathrm{Cr}$ was $\left(9926 \pm 235.84 \mu \mathrm{g} \mathrm{g}^{-1}\right.$ dry wt) at $10 \mathrm{mg} \mathrm{L}^{-1}$ with pH 5 and $25 \mu \mathrm{M}$ of EDTA after 10 days of treatment. The highest removal efficiency of Cr by L. minor was $99.26 \%$ at $10 \mathrm{mg} \mathrm{L}^{-1}$ with $\mathrm{pH} 5$ and $25 \mu \mathrm{M}$ of EDTA after 10 days of treatment. This study indicated that $\mathrm{pH}$ and EDTA influenced chromium accumulation in L. minor. The impact of the treated water by $L$. minor on the growth of Nile tilapia indicated that fish muscles had no chromium accumulation and the treated water became acceptable and safe. Meanwhile; a specific growth rate (SGR) was (1.2 $\pm 0.01 \% /$ day) at the end of exposure period which lasted 30 days the same as control group. So, we can conclude that Nile tilapia played an important role in monitoring chromium in the treated water by L. minor under the effect of $\mathrm{pH}$ and EDTA.
\end{abstract}

\section{INTRODUCTION}

In contaminated aquatic environments several toxic metals occur, often creating undesirable living conditions for many plants and animals (Divya et al., 2012). Among animal species, fishes are the inhabitants that cannot escape from the detrimental effects of heavy metals (Olaifa et al., 2004). One category of toxic contaminations accumulated by fishes is heavy metals such as lead $(\mathrm{Pb})$, mercury $(\mathrm{Hg})$, cadmium $(\mathrm{Cd})$, chromium $(\mathrm{Cr})$ and arsenic (As). Any of these heavy metals can destroy life when they concentrate in the 
body above acceptable levels (Nwabunike, 2016). Chromium contamination in water is a major concern, as various anthropogenic activities. Chromium toxicity in plants depends on its valence state (Oliveira, 2012). Chromium (Cr) has two stable forms $\mathrm{Cr}$ (VI) and $\mathrm{Cr}$ (III) amongst which Cr (VI) is more mobile and toxic than Cr (III) (Shanker et al., 2005). Chromium enter the aquatic ecosystem through effluents discharged from leather tanneries, textiles, electroplating, metal finishing, mining, dyeing and printing industries, ceramic, photographic and pharmaceutical industries etc. (Abbas and Ali, 2007). Fish assimilate $\mathrm{Cr}$ by ingestion or by the gill uptake tract and accumulation in fish tissues, mainly liver, occurs at higher concentrations than those found in the environment (Ahmed et al., 2013). Contaminated fish enter the human body through consumption and it causes health hazards (Nwabunike, 2016). Chronic chromium toxicity causes cancer in the respiratory tract and lungs (Thayaparan et al., 2015).

There are several methods for removing heavy metals from bodies of water. They can be ineffective and expensive. Therefore, there is an urgent need to adopt technology with optimum efficacy and low capital investment and can be acceptable for wide range of metal contamination (Kurniawan et al., 2006). Aquatic plants are considered to be simple, ecofriendly technology applicable for the removal of heavy metals from the aquatic medium (Perumal et al., 2010). Some aquatic plants have been investigated for their potential to improve wastewater quality because of their ability to grow in water polluted by heavy metals (Jafari and Akhavan, 2011). Aquatic plants play an important role in maintaining the purification capability of water and the entire aquatic ecosystem (Wang et al., 2008). Due to the high growth rate and large uptake metal potential, members of genus Lemna have been appeared as potential candidates for designing a duckweed-based heavy metal phytoremediation set-up (Rashmi and Surindra, 2015). In the field of ecotoxicology, Lemna spp. has been used for the removal of heavy metals from wastewater and constructed wetlands (Uysal and Taner, 2009). Duckweeds are able to remove and accumulate large amounts of heavy metals, principally through the fronds (Chaudhary and Sharma, 2014).

Metal bioaccumulation depends upon plant species, its organ and numerous abiotic factors like temperature, $\mathrm{pH}$, transportation of metal contaminated particles and dissolved ions in water (Divya et al., 2012). Metal toxicity is often dependent on $\mathrm{pH}$ in freshwater and soil. In metal uptake and chemical kinetic process, the role of initial metal load and $\mathrm{pH}$ of medium are very critical factors. Meanwhile, $\mathrm{pH}$ is deemed to offer a very decisive role in bioremediation process (Rashmi and Surindra, 2015). The chelator ethylene diamine tetra acetic acid (EDTA) is often included in nutrient media that are used to grow aquatic macrophytes. EDTA was often found to be the most effective (Grčman et al., 2001). When culturing duckweeds, the presence of a chelator is necessary for optimal growth (Landolt and Kandeler, 1987) and consistency between replicates (Hughes, 1991). EDTA may mobilize metal ions from river sediments and the resulting complexes may increase the uptake of metals such as cadmium, mercury, copper and chromium (Venier et al., 1987). Fish are widely used to evaluate the health of aquatic ecosystems because pollutants build up in the food chain and are responsible for adverse effects and death in the aquatic systems (Vinodhini and Narayanan, 2008). Various fish species are widely used as bioindicators of metal contamination (Svobodova et al., 2004).

The objective of this study was to evaluate the efficiency of the aquatic macrophyte L. minor in accumulation of different concentrations of chromium from polluted water 
under greenhouse conditions. So, we conducted a study with Lemna, 1) to determine the growth responses and accumulation of $\mathrm{Cr}$ in $L$. minor under effect of various levels of $\mathrm{pH}$ and different treatment periods; 2) to determine the growth responses and accumulation of $\mathrm{Cr}$ in L. minor under effect of various concentrations of EDTA and different treatment periods and 3) to assess the treatment impact of polluted water with chromium by $L$. minor under the effect of $\mathrm{pH}$ and EDTA on the growth of economically important organism (Nile tilapia).

\section{MATERIALS AND METHODS}

\subsection{Plant material and growth conditions}

The freshwater L. minor was collected from Soils \& Water and Environment Research Institute, Agricultural Research Center. The plant material was washed carefully to remove dirt, sludge and other adhesive debris from it. To avoid any contamination, the second generation of $L$. minor was obtained by culturing original individual in 1/10 diluted Hoagland's nutrient solution for 10 days as per standard methodology described by Eliasson (1978). Hoagland's nutrient solution was prepared according to Hoagland and Arnon (1950).

\subsection{Effect of $\mathrm{pH}$ on chromium accumulation in L. minor (Exp. 1)}

In this study, analytical grade of potassium dichromate salt $\left(\mathrm{K}_{2} \mathrm{Cr}_{2} \mathrm{O}_{7}\right)$ was used for the accumulation studies of $\mathrm{Cr}$ in L. minor fronds. The stock solution was prepared by dissolving $2.829 \mathrm{~g}$ of $\mathrm{K}_{2} \mathrm{Cr}_{2} \mathrm{O}_{7}$ in $1000 \mathrm{ml}$ of distilled water. Before the start of the experiment, the prominent and healthy plants were collected and rinsed with distilled water. One gram of plant material was placed in plastic pots contained $1000 \mathrm{ml}$ of $1 / 10$ Hoagland's nutrient solution for each treatment. Chromium concentrations were tested at $\left(0,2,4,6,8\right.$ and $\left.10 \mathrm{mg} \mathrm{L}^{-1}\right)$. To investigate the effect of $\mathrm{pH}$ on $\mathrm{Cr}$ accumulation in $L$. minor, test solutions were adjusted with $\mathrm{pH}(5,6,7,8$ and 9) either with $1 \mathrm{~N} \mathrm{NaOH}$ or with $1 \mathrm{~N} \mathrm{HCl}$ at the corresponding $\mathrm{Cr}$ concentrations. The initial $\mathrm{pH}$ of tested solutions was 5.8. Pots without $\mathrm{Cr}$ grown alongside the experimental groups served as control which were necessary to compare the results. All treatments were carried out in triplicate and exposed to natural sunlight in a greenhouse at a temperature of $37^{\circ} \mathrm{C} \pm 2$ for four different periods $(5,10,15$ and 20 days). The evaporation loss was compensated weekly.

\subsection{Effect of EDTA on chromium accumulation in L. minor at pH 5 (Exp. 2)}

Different concentrations of $\mathrm{Cr}$ were prepared at $\left(0,2,4,6,8\right.$ and $\left.10 \mathrm{mg} \mathrm{L}^{-1}\right)$ and different concentrations of $\mathrm{Na}_{2}$ - EDTA were separately added at $(25,50,75$ and $100 \mu \mathrm{M})$. All solutions were adjusted with $\mathrm{pH}$ 5. One gram of plant material was placed in plastic pots contained $1000 \mathrm{ml}$ of $1 / 10$ Hoagland's nutrient solution for each treatment. Experimental set-ups with zero $\mathrm{Cr}$ concentration served as control. All treatments were carried out in triplicate at a temperature of $35^{\circ} \mathrm{C} \pm 2$ under greenhouse conditions for four different periods $(5,10,15$ and 20 days). The evaporation loss was compensated weekly.

\subsection{Plant growth parameters}

After completion of each treatment period, the plant samples were harvested, washed thoroughly three times with distilled water to remove any chromium on the plant surface and then kept on filter paper for few seconds to remove excess liquid. Fresh weight (f.wt) was recorded immediately. The plant samples were dried at $100^{\circ} \mathrm{C}$ for 10 min, then at $70^{\circ} \mathrm{C}$ for $24 \mathrm{hr}$ until completely dry and the dry weight (d.wt) was recorded. Fresh and dry weights of L. minor were given as $\mathrm{g} \mathrm{m}^{-2}$ (El- Berashi, 2008). 


\subsection{Analysis of chromium accumulation in L. minor tissues}

Two hundred milligrams of the plant samples were first digested with $\mathrm{HNO}_{3}$ followed by $\mathrm{HClO}_{4}(3: 1)$ on hot plate and during that temperature was raised to about $95^{\circ} \mathrm{C}$. The temperature was maintained until nitrous gas evolution stopped and the digest was clear (Kara, 2004). The digest was then made up to a final volume of $10 \mathrm{ml}$ in polythene tubes with dilution. Determination of $\mathrm{Cr}$ concentrations in plant tissue was carried out by inductively coupled plasma optical emission spectroscopy (ICP-OES) according to Duman et al. (2009). Chromium accumulation in L. minor tissues was calculated on dry weights basis and expressed as $\mu \mathrm{g} \mathrm{g}^{-1}$ dry wt.

\subsection{Estimation of bioconcentration factor}

Bioconcentration factor (BCF) which is a useful parameter (Lu et al., 2004) to evaluate the potential of plants for accumulating metals. BCF for $\mathrm{Cr}$ was calculated by dividing metal concentration in plant's tissue $\left(\mu \mathrm{g} \mathrm{g}^{-1} \mathrm{dry} \mathrm{wt}\right)$ with the initial concentration of the metal in nutrient solution.

\subsection{Removal efficiency of chromium by $L$. minor}

In order to investigate the removal efficiency of $\mathrm{Cr}$ at $2,4,6,8$ and $10 \mathrm{mg} \mathrm{L}^{-1}$ by $L$. minor, the residual concentration of $\mathrm{Cr}$ was determined in nutrient solutions after 5, 10, 15 and 20 days with $\mathrm{pH} 5$ and $25 \mu \mathrm{M}$ of EDTA. Water samples were collected under plant mat in polyethylene bottles from each pot to measure $\mathrm{Cr}$ concentrations. The water samples were digested according to (Kara, 2004). The residual concentration of $\mathrm{Cr}$ in the solution was quantified using (ICP). The percentage metal efficiency was calculated according to Tanhan et al., (2007).

$$
\% \text { efficiency }=\left(\mathrm{C}_{0}-\mathrm{C}_{1}\right) / \mathrm{C}_{0} \times 100
$$

$\mathrm{C}_{0}$ and $\mathrm{C}_{1}$ are initial and residual concentrations of metal in medium $\left(\mathrm{mg} \mathrm{L}^{-1}\right)$.

\subsection{Effect of the treated water on Nile tilapia growth (Exp. 3)}

\subsubsection{Fish collection and growth conditions}

Fishes were purchased from a commercial fish farm. Fishes were immediately transferred to glass aquaria and randomly distributed at a stocking density of 10 fish per aquarium under laboratory conditions for two weeks. The experiment was carried out in experimental aquaria of the dimensions; $75 \mathrm{~cm}$ (length), $40 \mathrm{~cm}$ (width) and $50 \mathrm{~cm}$ (height) with a total volume of $40 \mathrm{~L}$ of dechlorinated tap water. Experimental aquaria were supplied with well-aerated in a recirculating system at a temperature of $27^{\circ} \mathrm{C}$. Aquaria were continously cleaned and the water exchange including fish feces and remaining food. The fishes were fed with standard powdered feed twice daily and were starved for $24 \mathrm{hr}$ prior to the experiment.

\subsubsection{Experimental design}

This experiment was conducted to assess the treatment impact by L. minor on Nile tilapia growth. The treatment was carried out in aquaria which described as previous, then filled with $40 \mathrm{~L}$ of $1 / 10$ Hoagland's nutrient solution and one gram of plant material was exposed to $10 \mathrm{mg} \mathrm{L}^{-1}$ of $\mathrm{Cr}$ per litre with $\mathrm{pH} 5$ and $25 \mu \mathrm{M}$ of EDTA. Aquaria supplied with plant and without $\mathrm{Cr}$ served as control. The treatments were carried out in triplicate under greenhouse conditions at a temperature of $35^{\circ} \mathrm{C} \pm 2$ for 10 days.

\subsubsection{Exposure of Nile tilapia to the treated water}

The treated water was collected from each aquarium and transferred to other clean aquaria. Healthy fishes were collected and weighed for the next experiment. Average 
initial weight and length of fish were $(30.5 \pm 1.61 \mathrm{gm}$ and $21.6 \pm 1.0 \mathrm{~cm})$ respectively. Five individuals of fish were exposed to the treated water per each aquarium under laboratory conditions for 30 days with a continuous aeration at a temperature of $27^{\circ} \mathrm{C}$. For comparison, similar set of aquaria was also kept wherein fish was grown in dechlorinated tap water served as control. The fishes were fed with powdered feed twice daily.

\subsubsection{Estimation of growth parameters}

At the end of exposure period which lasted 30 days, fishes were caught from each aquarium and then washed thoroughly with distilled water. The average final weight and length of exposed fish and control group were measured. Specific growth rate of fish was calculated according to Khattab (1996).

Specific growth rate $(\mathrm{SGR}, \% /$ day $)=\left(\operatorname{In} \mathrm{W}_{\mathrm{t}}-\mathrm{In} \mathrm{W}_{0}\right) / \mathrm{T} X 100(\mathrm{In}=$ natural logarithm; $\mathrm{W}_{0}=$ initial weight; $\mathrm{W}_{\mathrm{t}}=$ final weight; and $\mathrm{T}=$ time in day).

\subsubsection{Analysis of chromium accumulation in fish muscles}

Fishes were dissected to extract a $10 \mathrm{gm}$ sample of the fish muscles and were dried in oven at $100^{\circ} \mathrm{C} \pm 1$ for $3 \mathrm{hr}$. Two grams of the dried samples were put in a $250 \mathrm{ml}$ conical flask and then subjected to acid digestion with nitric acid and perchloric acid (4:1). The flasks were then cooled at room temperature and the residues were dissolved in $10 \mathrm{ml}$ of dilute nitric acid and filtered. The filtrate was diluted to $50 \mathrm{ml}$ with distilled water (Frank, 1984). Chromium analysis was estimated using ICP and the results were expressed as $\mu \mathrm{g} \mathrm{g}^{-1}$ dry wt.

\subsection{Statistical analysis}

The mean and standard deviation (S.D) of three replicates for each treatment and control group were calculated. The results of the effect of $\mathrm{pH}$ and EDTA on fresh, dry weights of L. minor and accumulation of $\mathrm{Cr}$ by $L$. minor for each concentration at all treatment periods in all experimental set-ups were statistically analyzed by one-way ANOVA at $P<0.05$ using Tukey test.

\section{RESULTS}

\subsection{Effect of different concentrations of $\mathrm{Cr}$ and $\mathrm{pH}$ on growth of $\mathrm{L}$. minor}

Results of fresh and dry weights of L. minor were taken after 5, 10, 15 and 20 days of treatment to assess the effect of different concentrations of $\mathrm{Cr}(0,2,4,6,8$ and $10 \mathrm{mg}$ $\left.\mathrm{L}^{-1}\right)$ and $\mathrm{pH}(5,6,7,8$ and 9) (Fig. 1). Fresh and dry weights of L. minor gradually increased with increasing $\mathrm{Cr}$ concentrations as compared to control after 5 and 10 days of treatment. Also, fresh and dry weights were positively affected by $\mathrm{pH} 5>\mathrm{pH}$ 6> pH 7> $\mathrm{pH} 8>\mathrm{pH} 9$ during all treatment periods. However, the highest fresh and dry weight of $L$. minor was $\left(1053.29 \pm 25.21 \mathrm{~g} \mathrm{~m}^{-2}\right.$ f.wt and $\left.73.73 \pm 3.53 \mathrm{~g} \mathrm{~m}^{-2} \mathrm{~d} . \mathrm{wt}\right)$ at $10 \mathrm{mg} \mathrm{L}^{-1}$ of Cr with $\mathrm{pH} 5$ after 10 days of treatment. Fresh and dry weights were dependent on the concentrations of $\mathrm{Cr}$ and $\mathrm{pH}$. Furthermore, the results of fresh and dry weights with $\mathrm{pH} 5$ were significantly different compared to $\mathrm{pH}(6,7,8$ and 9$)$ at $P<0.05$.

\subsection{Effect of pH on accumulation of $\mathrm{Cr}$ in $L$. minor}

Similarly, chromium accumulation in L. minor was also gradually increased with increasing $\mathrm{Cr}$ concentrations with $\mathrm{pH}(5,6,7,8$ and 9) after 5 and 10 days of treatment (Table 1). All experimental set-ups with different $\mathrm{pH}$ range can be arranged as in terms of accumulation efficacy: $\mathrm{pH} 5>\mathrm{pH}$ 6> $\mathrm{pH}$ 7> $\mathrm{pH} 8>\mathrm{pH} 9$ during all treatment periods. Overall, the highest accumulation of $\mathrm{Cr}$ was $\left(9563.81 \pm 222.47 \mu \mathrm{g} \mathrm{g}^{-1} \mathrm{dry} w \mathrm{wt}\right)$ at $10 \mathrm{mg} \mathrm{L}^{-1}$ with $\mathrm{pH} 5$ after 10 days of treatment. The accumulation of $\mathrm{Cr}$ in L. minor with $\mathrm{pH} 5$ was significantly different compared to $\mathrm{pH}(6,7,8$ and 9$)$ at $P<0.05$. 

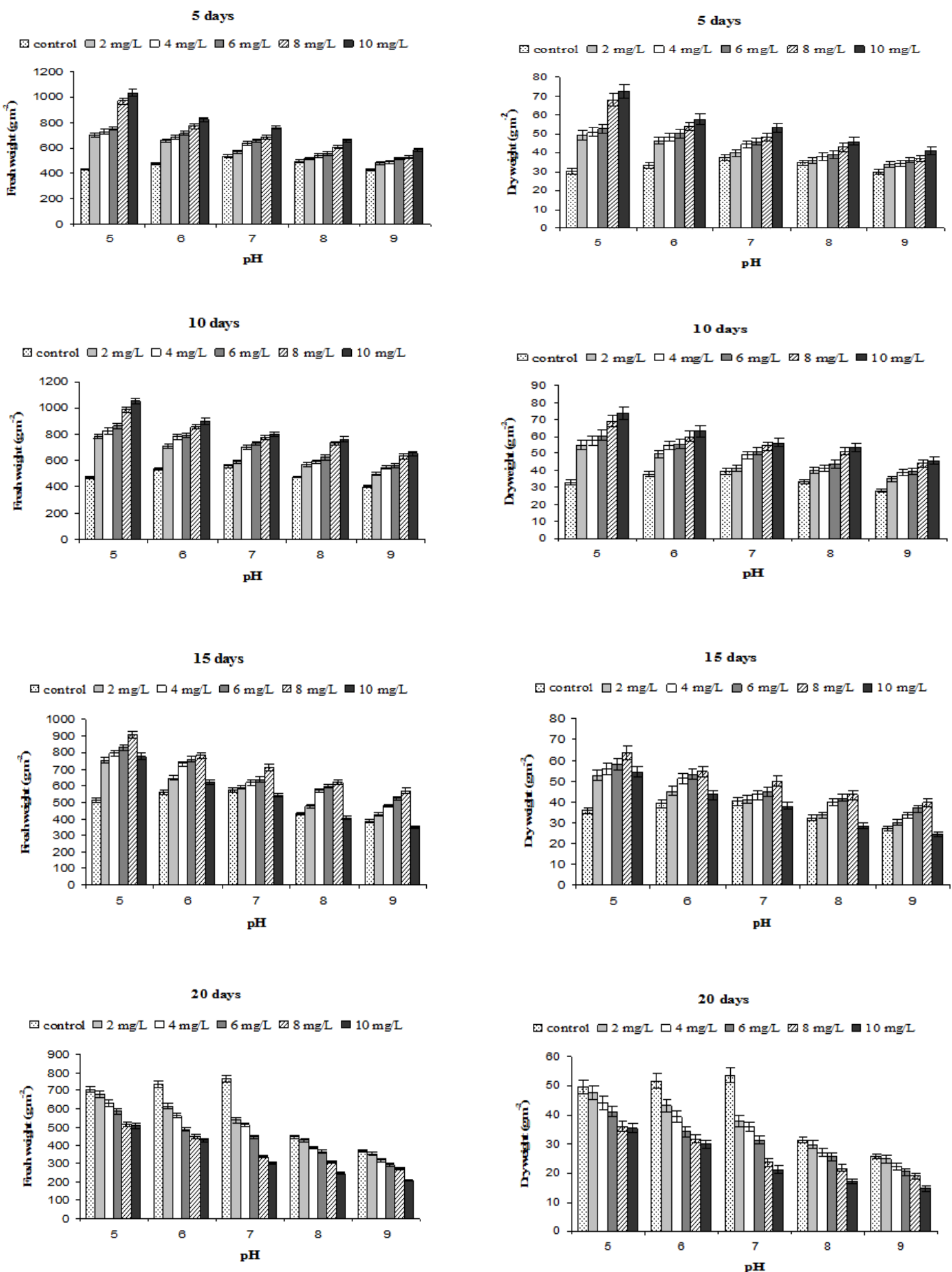

Fig. (1): Effect of different concentrations of $\mathrm{Cr}$ and $\mathrm{pH}$ on fresh and dry weights of $L$. minor after different treatment periods. 
Table (1): Effect of $\mathrm{pH}$ on accumulation of $\mathrm{Cr}$ in L. minor after different treatment periods.

\begin{tabular}{|c|c|c|c|c|c|c|c|c|}
\hline \multirow{2}{*}{$\begin{array}{l}\text { Treatment } \\
\text { periods } \\
\text { (day) }\end{array}$} & \multirow{2}{*}{$\begin{array}{c}\mathrm{Cr} \\
\text { concentration } \\
\left.(\mathrm{mg} \mathrm{L})^{-1}\right)\end{array}$} & \multicolumn{5}{|c|}{ 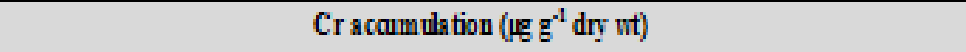 } & \multirow{2}{*}{$\underset{\text { valie }}{F-}$} & \multirow{2}{*}{$\begin{array}{c}\text { P. } \\
\text { valte }\end{array}$} \\
\hline & & $\mathrm{pH} 5$ & pH6 & $\mathrm{pH}$ ? & $\mathrm{pH} 8$ & $\mathrm{pH} 9$ & & \\
\hline \multirow{5}{*}{5} & 2 & $1621.70^{2} \pm 6637$ & $152702^{2} \pm 64.10$ & $114354^{c} \pm 5399$ & $102123^{c} \pm 5661$ & $866.61^{\circ 4} \pm j 9.83$ & 162.00 & 0.000 \\
\hline & 4 & $330053^{2} \pm 93.71$ & $263322^{2} \pm 6533$ & $132930^{\circ}=5554$ & $123930^{\circ}=5484$ & $93123^{4} \pm 4011$ & 144.18 & 0.000 \\
\hline & 6 & $531455^{2} \pm 10921$ & $2750.85^{2} \pm 75.88$ & $174240^{c} \pm 5288$ & $172161^{\circ} \pm 5593$ & $160965^{c} \pm 5320$ & 176.09 & 0.000 \\
\hline & 8 & $7371.44^{2} \pm 123.84$ & $445059^{2} \pm 94.74$ & $2272.47^{c} \pm 71.73$ & $207702^{c}=7311$ & $189350^{\circ 4} \pm 5007$ & 17894 & 0.000 \\
\hline & 10 & $916912^{2}=22392$ & $604062^{2} \pm 131.76$ & $350325^{\circ} \pm 8065$ & $314091^{\varsigma}=7802$ & $238509^{d} \pm 72.56$ & 160.77 & 0.000 \\
\hline \multirow{5}{*}{10} & 2 & $171629^{1} \pm 9397$ & $167433^{2} \pm 7723$ & $133895^{\circ} \pm 6363$ & $1262.75^{\complement} \pm 53.64$ & $1104.72^{4} \pm 5167$ & 108.4 & 0.000 \\
\hline & 4 & $366249^{2} \pm 118.95$ & $311253^{2} \pm 98.64$ & $249930^{c} \pm 7096$ & $219933^{4} \pm 62.96$ & $215433^{4} \pm 5890$ & 73222 & 0.000 \\
\hline & 6 & $5477.61^{2} \pm 163.50$ & $511632^{2} \pm 12186$ & $415404^{6}=90.47$ & $310392^{d} \pm 79.35$ & $257319^{d} \pm 82.72$ & 9725 & 0.000 \\
\hline & 8 & $759761^{2} \pm 213.70$ & $649296^{2} \pm 15489$ & $508008^{\complement} \pm 111.53$ & $329895^{d} \pm 82.36$ & $311319^{d} \pm 88.98$ & 818.59 & 0.000 \\
\hline & 10 & $956381^{2} \pm 222.47$ & $728334^{2} \pm 17135$ & $6138.72^{6} \pm 146.82$ & $389556^{4} \pm 99.58$ & $355626^{4} \pm 89.63$ & 908.55 & 0.000 \\
\hline \multirow{5}{*}{15} & 2 & $157822^{2} \pm 9034$ & $134509^{2} \pm 75.63$ & $119927^{\circ} \pm 55.77$ & $104009^{d} \pm 5493$ & $102465^{\circ}=4980$ & 704.75 & 0.000 \\
\hline & 4 & $310708^{2} \pm 113.51$ & $2847.78^{2} \pm 72.06$ & $198192^{2}=6529$ & $159003^{d} \pm 58.14$ & $139851^{d} \pm 54.70$ & 101.20 & 0.000 \\
\hline & 6 & $544401^{2} \pm 13734$ & $389781^{8} \pm 84.71$ & $2440.44^{5} \pm 0357$ & $228240^{\circ}=5320$ & $186003^{d} \pm 56.21$ & 879.87 & 0.000 \\
\hline & 8 & $711264^{2} \pm 190.71$ & $5741.73^{2} \pm 15527$ & $389781^{\varsigma}=107.88$ & $259398^{4}=72.69$ & $211392 \pm 7015$ & 97992 & 0.000 \\
\hline & 10 & $505287^{2} \pm 121.18$ & $351360^{2} \pm 90.60$ & $311895^{\circ} \pm 8204$ & $1992.78^{d} \pm 64.18$ & $162468^{\circ} \pm 4582$ & 772.13 & 0.000 \\
\hline \multirow{5}{*}{20} & 2 & $133702^{2} \pm 81.70$ & $129202^{2} \pm 6733$ & $114868^{\circ} \pm 5913$ & $109013^{4} \pm 53.74$ & $838.89=45.26$ & 742.55 & 0.000 \\
\hline & 4 & $12924^{2} \pm 7552$ & $12293^{2} \pm 5490$ & $112454^{c} \pm 53.44$ & $1003.44 \pm 52.62$ & $778.86 \pm 46.76$ & 782.82 & 0.000 \\
\hline & 6 & $118892^{2} \pm 6713$ & $111023^{2} \pm 57.56$ & $10112=48.20$ & $821.61^{4}=4555$ & $747.72^{4} \pm 3836$ & 832.47 & 0.000 \\
\hline & 8 & $1107.75^{2} \pm 6720$ & $10055^{2} \pm 4999$ & $938.51 \leq 47.85$ & $700.38^{4} \pm 3698$ & $613.899^{4} \pm 3592$ & 948.92 & 0.000 \\
\hline & 10 & $998.51^{2} \pm 6014$ & $935.03^{8} \pm 47.85$ & $811.17 \pm 4490$ & $437.31^{4}=2680$ & $371.52^{4}=2522$ & 112.23 & 0.000 \\
\hline
\end{tabular}

* Data are presented as mean of three samples \pm S.D, F-value: the difference among $\mathrm{pH}$ at each concentration of $\mathrm{Cr}$ (one-way ANOVA). The same letters refer to insignificant results and the different letters refer to significant results at $P<0.05$.

\subsection{Effect of $\mathrm{pH}$ on bioconcentration factor $(\mathrm{BCF})$ for $\mathrm{Cr}$}

The results of bioconcentration factor $(\mathrm{BCF})$ for $\mathrm{Cr}$ with different levels of $\mathrm{pH}$ after different treatment periods are shown in Fig. 2. It is clear that L. minor showed comparatively high $\mathrm{BCF}$ values for $\mathrm{Cr}$ in experimental set-up with $\mathrm{pH}$ 5. In terms of $\mathrm{pH}$ of media, the set-ups for $\mathrm{BCF}$ of $\mathrm{Cr}$ can be arranged in the order: $\mathrm{pH} 5>\mathrm{pH} 6>\mathrm{pH} 7>\mathrm{pH}$ $8>\mathrm{pH}$ 9. The highest value of $\mathrm{BCF}$ for $\mathrm{Cr}$ was $(956.38 \pm 23.69)$ at $10 \mathrm{mg} \mathrm{L}^{-1}$ with $\mathrm{pH} 5$ after 10 days of treatment. However, the higher value of BCF indicates the ability of $L$. minor to accumulate higher concentrations of chromium in its tissues. 

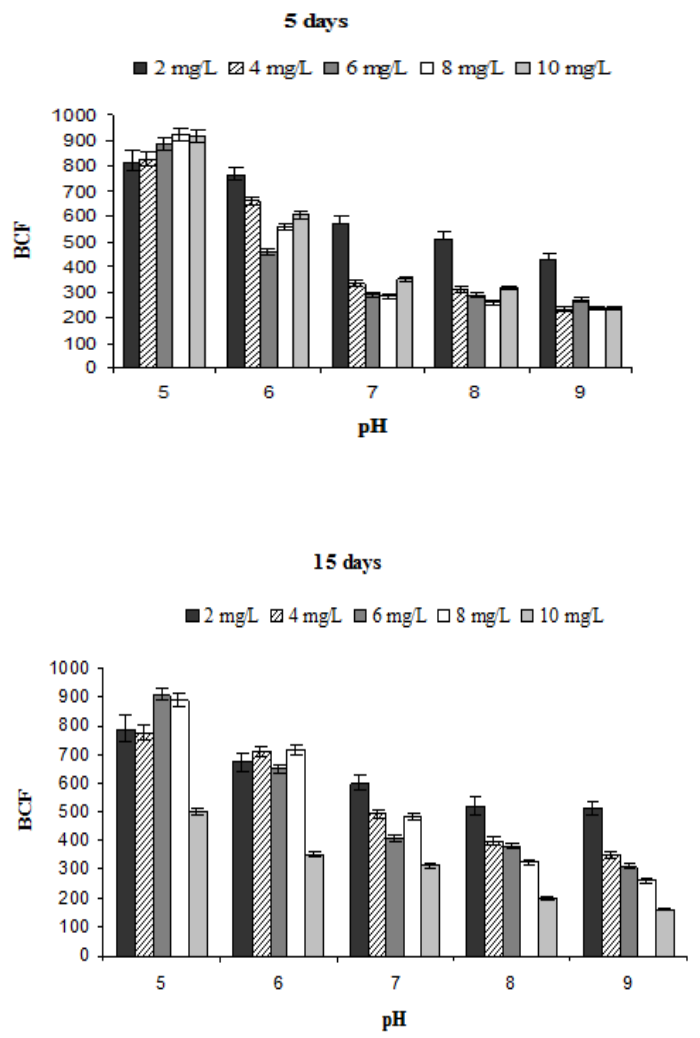
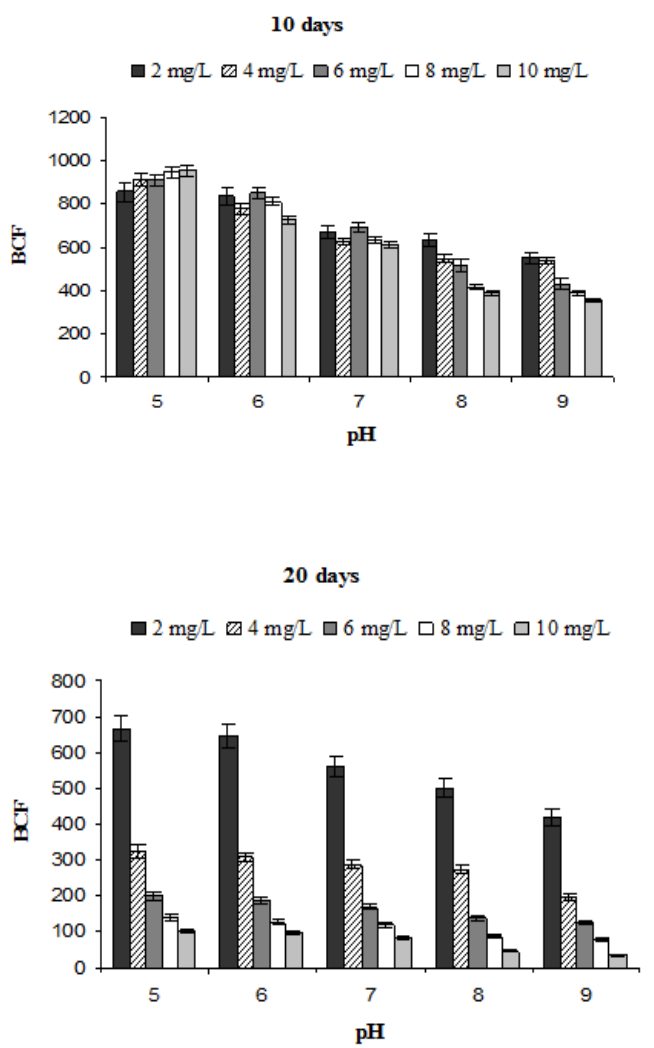

Fig. (2): Effect of $\mathrm{pH}$ on bioconcentration factor $(\mathrm{BCF})$ for $\mathrm{Cr}$ after different treatment periods.

\subsection{Effect of different concentrations of $\mathrm{Cr}$ and EDTA on growth of $L$. minor at pH 5}

The previous results indicated that L. minor showed better growth and $\mathrm{Cr}$ accumulation at $10 \mathrm{mg} \mathrm{L}^{-1}$ of $\mathrm{Cr}$ with $\mathrm{pH}$ 5. In test sets supplemented with EDTA concentrations $(25,50,75$ and $100 \mu \mathrm{M})$, growth of $L$. minor was affected by different concentrations of $\mathrm{Cr}$ in medium with $\mathrm{pH} 5$ after 5, 10, 15 and 20 days of treatment (Fig. $3)$. The highest fresh and dry weight of $L$. minor was $\left(1267.54 \pm 29.63 \mathrm{~g} \mathrm{~m}^{-2} \mathrm{f}\right.$.wt and $88.73 \pm 4.15 \mathrm{~g} \mathrm{~m}^{-2} \mathrm{~d}$.wt) at $10 \mathrm{mg} \mathrm{L}^{-1}$ of $\mathrm{Cr}$ with $\mathrm{pH} 5$ and $25 \mu \mathrm{M}$ of EDTA after 10 days of treatment. The effect was more pronounced in treatments EDTA 25>50>75>100 $\mu \mathrm{M}$ during all treatment periods. Meanwhile, the results of fresh and dry weights with $25 \mu \mathrm{M}$ of EDTA were significant compared to EDTA $(50,75$ and $100 \mu \mathrm{M})$ at $P<0.05$ after 10 days of treatment.

\subsection{Effect of EDTA on accumulation of $\mathrm{Cr}$ in $L$. minor at $\mathrm{pH} 5$}

The results of this experiment indicated that $L$. minor had the capacity to accumulate large quantities of $\mathrm{Cr}$ in solutions containing different concentrations of EDTA. Chromium is chelated by different concentrations of EDTA with pH 5 (Table 2). Maximum accumulation of $\mathrm{Cr}$ was $\left(9926 \pm 235.84 \mu \mathrm{g} \mathrm{g}^{-1}\right.$ dry wt) at $10 \mathrm{mg} \mathrm{L}^{-1}$ with $25 \mu \mathrm{M}$ of EDTA after 10 days of treatment. The results revealed that $\mathrm{Cr}$ accumulation increased significantly $(P<0.05)$ at $10 \mathrm{mg} \mathrm{L}^{-1}$ with $25 \mu \mathrm{M}$ of EDTA compared to EDTA $(50,75$ and $100 \mu \mathrm{M})$ after 10 days of treatment. 

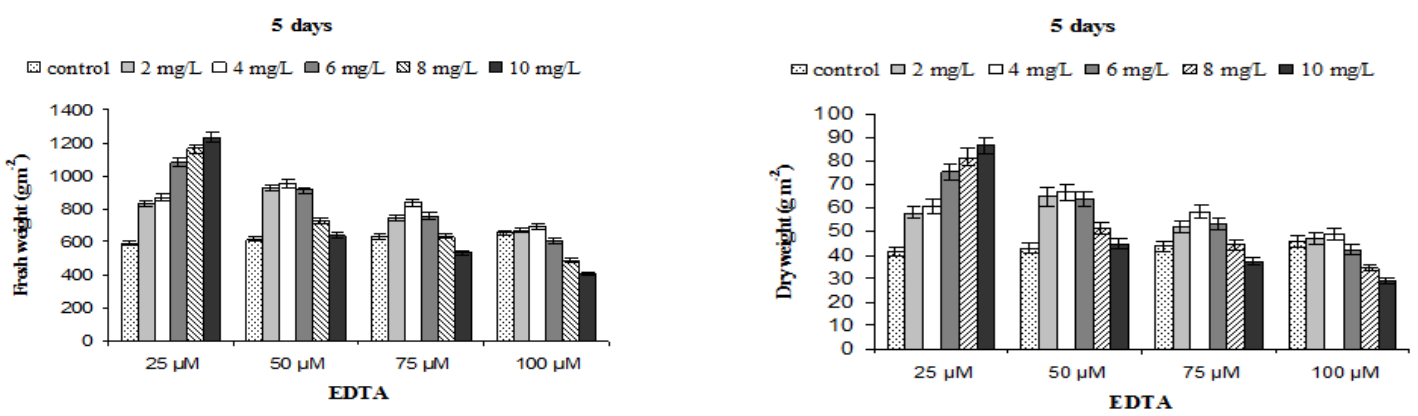

10 days

10 days

중 control $\square 2 \mathrm{mg} L \square 4 \mathrm{mg} / \square 6 \mathrm{mgL} \square 8 \mathrm{mgL} \square 10 \mathrm{mg} /$

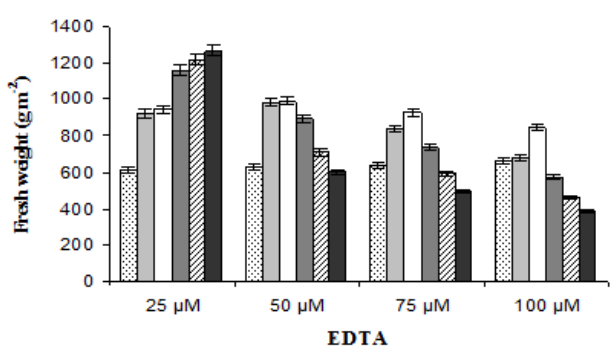

○control $\square 2 \mathrm{mg} / \square 4 \mathrm{mg} / \square 6 \mathrm{mgL} \square 8 \mathrm{mgL} \square 10 \mathrm{mg} / \mathrm{L}$

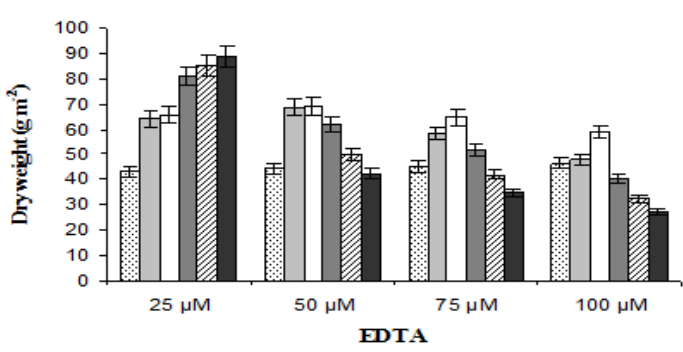

15 days

15 days

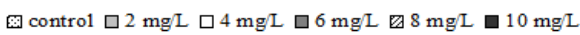

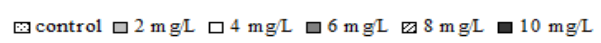
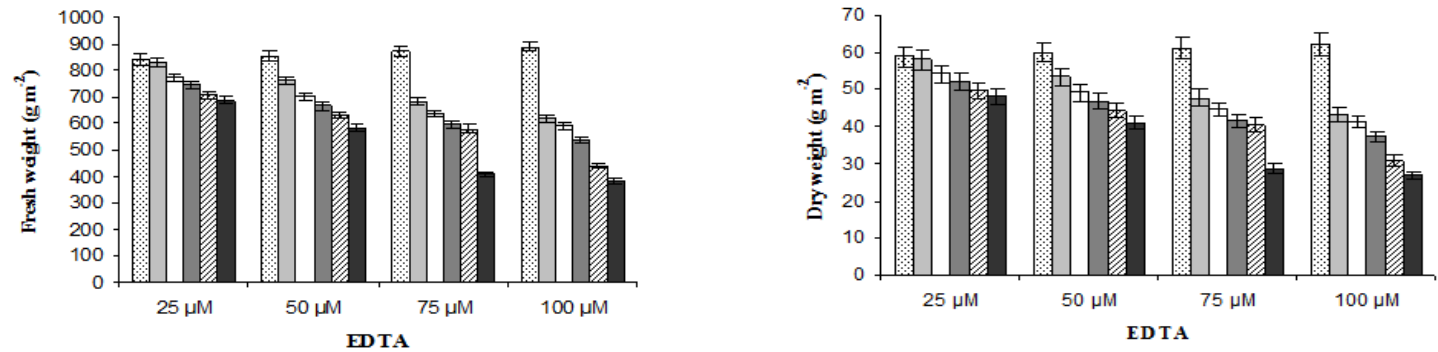

20 days

园 control $\square 2 \mathrm{mg} L \square 4 \mathrm{mg} / \square 6 \mathrm{mgL} \square 8 \mathrm{mgL} \square 10 \mathrm{mgL}$

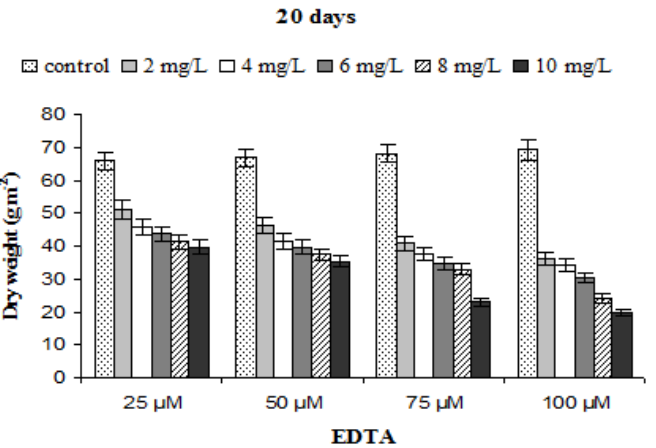

Fig. (3): Effect of different concentrations of Cr and EDTA on fresh and dry weights of $L$. minor at $\mathrm{pH} 5$ after different treatment periods. 
Table (2): Effect of EDTA on accumulation of $\mathrm{Cr}$ in L. minor at $\mathrm{pH} 5$ after different treatment periods.

\begin{tabular}{|c|c|c|c|c|c|c|c|}
\hline \multirow{2}{*}{$\begin{array}{c}\text { Treatment } \\
\text { periods } \\
\text { (day) }\end{array}$} & \multirow{2}{*}{$\begin{array}{c}\mathrm{Cr} \\
\text { concentration } \\
\left(\mathrm{mg} \mathrm{L}^{4}\right)\end{array}$} & \multicolumn{4}{|c|}{ 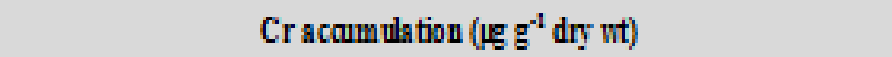 } & \multirow{2}{*}{$\underset{\text { valie }}{F-}$} & \multirow{2}{*}{$\underset{\text { value }}{P-}$} \\
\hline & & $\begin{array}{l}\text { EDTA } \\
(25 \Perp M)\end{array}$ & $\begin{array}{l}\text { EDTA } \\
(50 \mu M)\end{array}$ & $\begin{array}{l}\text { EDTA } \\
(75 \mu M)\end{array}$ & $\begin{array}{c}\text { EDTA } \\
(100 \mu \mathrm{M})\end{array}$ & & \\
\hline \multirow{5}{*}{5} & 2 & $170839^{2} \pm 117.63$ & $162336^{2} \pm 11986$ & $147208^{\circ}=109.29$ & $122307^{4} \pm 99.05$ & 109.14 & 0.000 \\
\hline & 4 & $348514^{2} \pm 132.71$ & $333324^{2} \pm 12883$ & $318705^{2} \pm 12929$ & $302431^{\circ}=109.00$ & 7303 & 0.000 \\
\hline & 6 & $542299^{2} \pm 158.17$ & $325640^{2} \pm 12111$ & $279493^{\circ} \pm 110.84$ & $181429^{d}=10055$ & 298.98 & 0.000 \\
\hline & 8 & $7420.47^{2} \pm 204.80$ & $311791^{8} \pm 11947$ & $268792^{5} \pm 120.45$ & $1633.75^{d} \pm 95.55$ & 69398 & 0.000 \\
\hline & 10 & $928560^{2} \pm 23239$ & $3006.76^{2} \pm 122.77$ & $2441.77^{\circ} \pm 2200$ & $140614^{4} \pm 83.95$ & 130.50 & 0.000 \\
\hline \multirow{5}{*}{10} & 2 & $177019^{2} \pm 126.54$ & $168247^{2} \pm 11767$ & $152802^{5} \pm 116.30$ & $132603^{4} \pm 9320$ & 102.38 & 0.000 \\
\hline & 4 & $372101^{2} \pm 153.42$ & $328294^{2} \pm 120.41$ & $298664^{6}=103.72$ & $233375^{d} \pm 10515$ & 155.91 & 0.000 \\
\hline & 6 & $567416^{2} \pm 174.15$ & $156191^{8}=11964$ & $148829^{6}=112.65$ & $128857^{4} \pm 87.23$ & 455.33 & 0.000 \\
\hline & 8 & $7653.48^{2} \pm 210.92$ & $140385^{2} \pm 12123$ & $133431^{c}=9118$ & $116132^{4} \pm 88.26$ & 917.87 & 0.000 \\
\hline & 10 & $9926^{2} \pm 235.84$ & $122381^{8} \pm 10782$ & $115117^{\star} \pm 8252$ & $109025^{4} \pm 79.71$ & 169.60 & 0.000 \\
\hline \multirow{5}{*}{15} & 2 & $168984^{2} \pm 113.66$ & $155991^{8} \pm 11268$ & $135420^{\circ} \pm 114.45$ & $123993^{4}=10085$ & 83.44 & 0.000 \\
\hline & 4 & $1596.49^{2}=114.89$ & $1476.69^{2}=110.49$ & $131124^{c}=9915$ & $120561^{d} \pm 94.44$ & 7108 & 0.000 \\
\hline & 6 & $1443.72^{2} \pm 100.72$ & $135826^{2} \pm 9920$ & $129152^{c} \pm 9623$ & $111433^{d} \pm 93.34$ & 10491 & 0.000 \\
\hline & 8 & $132655^{2} \pm 100.42$ & $1299.74^{8} \pm 91.85$ & $1245.48^{c} \pm 8681$ & $1038.12^{d 4} \pm 86.04$ & 122.10 & 0.000 \\
\hline & 10 & $128309^{2} \pm 9732$ & $119935^{2} \pm 87.69$ & $112343^{c} \pm 7385$ & $974.42^{d} \pm 6831$ & 184.14 & 0.000 \\
\hline \multirow{5}{*}{20} & 2 & $134055^{1} \pm 82.73$ & $109128^{2} \pm 79.03$ & $106417^{c} \pm 0933$ & $1012^{4} \pm 78.11$ & 12391 & 0.000 \\
\hline & 4 & $126330^{2} \pm 7694$ & $106591^{2} \pm 77.17$ & $103905^{\varsigma} \pm 65.70$ & $992.76^{4} \pm 6397$ & 108.68 & 0.000 \\
\hline & 6 & $121357^{x} \pm 8113$ & $1017^{8} \pm 68.93$ & 984.97459 .13 & $966.24^{4} \pm 5734$ & 217.23 & 0.000 \\
\hline & 8 & $1149.46^{2} \pm 63.73$ & $991.46^{2} \pm 7125$ & $931.18 \pm 58.84$ & $857.43^{d} \pm 5423$ & 139.50 & 0.000 \\
\hline & 10 & $106282^{2} \pm 58.73$ & $954.12^{2} \pm 61.43$ & $872.63 \pm 49.64$ & $837.14^{4} \pm 3988$ & 8238 & 0.000 \\
\hline
\end{tabular}

* Data are presented as mean of three samples \pm S.D, F-value: the difference among concentrations of EDTA with each concentration of $\mathrm{Cr}$ (one-way ANOVA). The same letters refer to insignificant results and the different letters refer to significant results at $P<0.05$.

\subsection{Effect of EDTA on bioconcentration factor (BCF) for $\mathrm{Cr}$ at $\mathrm{pH} 5$}

The results of bioconcentration factor (BCF) for $\mathrm{Cr}$ with different concentrations of EDTA at $\mathrm{pH} 5$ are shown in Fig. 4. The highest value of BCF for $\mathrm{Cr}$ was (992.6 \pm 24.56$)$ at $10 \mathrm{mg} \mathrm{L}^{-1}$ with $25 \mu \mathrm{M}$ of EDTA after 10 days of treatment. 
5 days

【 $2 \mathrm{mg} / \mathrm{L} \square 4 \mathrm{mg} / \mathrm{L} \square 6 \mathrm{mg} / \mathrm{L} 8 \mathrm{mg} / \mathrm{L} \square 10 \mathrm{mg} / \mathrm{L}$

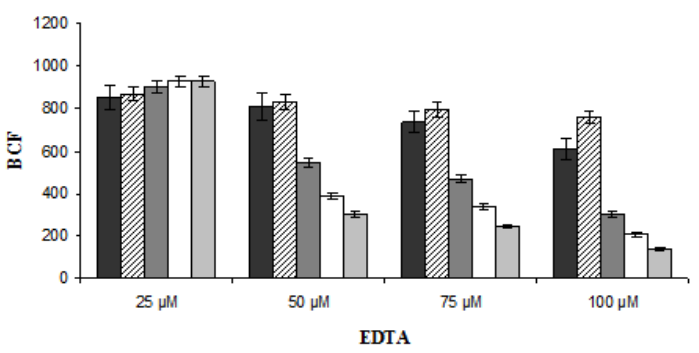

15 days

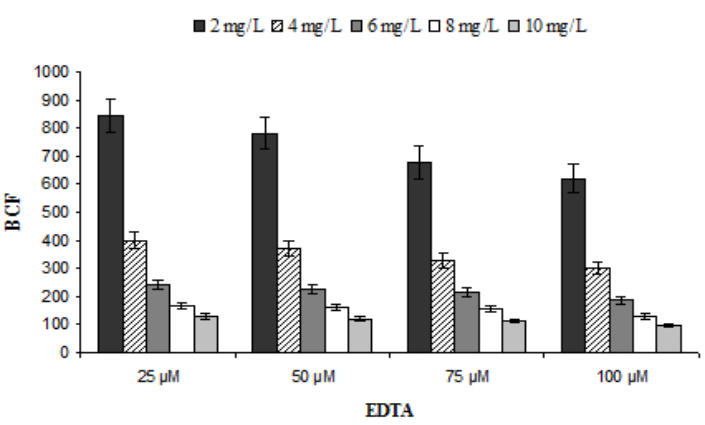

10 days

घ $2 \mathrm{mg} / \mathrm{L} \square 4 \mathrm{mg} / \mathrm{L} \square 6 \mathrm{mg} / \mathrm{L} \square 8 \mathrm{mg} / \mathrm{L} \square 10 \mathrm{mg} / \mathrm{L}$

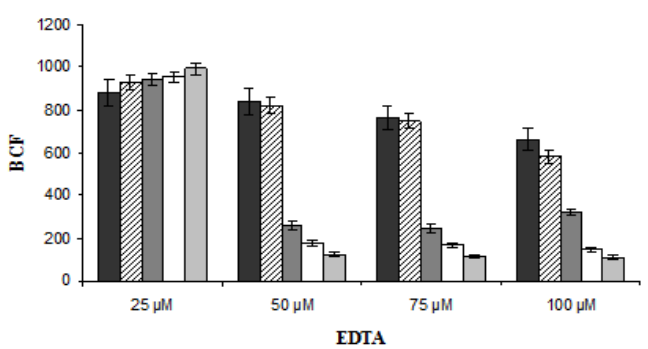

20 days

घ $2 \mathrm{mg} / \mathrm{L}$ घ $4 \mathrm{mg} / \mathrm{L} \square 6 \mathrm{mg} / \mathrm{L} \square 8 \mathrm{mg} / \mathrm{L}$ 口 $10 \mathrm{mg} / \mathrm{L}$

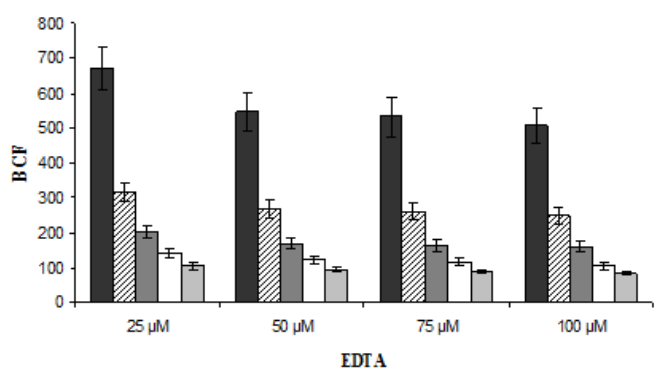

Fig. (4): Effect of EDTA on bioconcentration factor ((BCF) for $\mathrm{Cr}$ after different treatment periods.

\subsection{Removal efficiency of chromium by $L$. minor}

Effect of $\mathrm{pH} 5$ and $25 \mu \mathrm{M}$ of EDTA on removal efficiency of different concentrations of $\mathrm{Cr}$ by L. minor after different treatment periods is shown in Fig. 5. The highest removal efficiency of $\mathrm{Cr}$ by L. minor was $99.26 \%$ at $10 \mathrm{mg} \mathrm{L}^{-1}$ after 10 days of treatment.

$\square 2 \mathrm{mg} / \mathrm{L} \square 4 \mathrm{mg} / \mathrm{L} \square 6 \mathrm{mg} / \mathrm{L} \square 8 \mathrm{mg} / \mathrm{L} \square 10 \mathrm{mg} / \mathrm{L}$

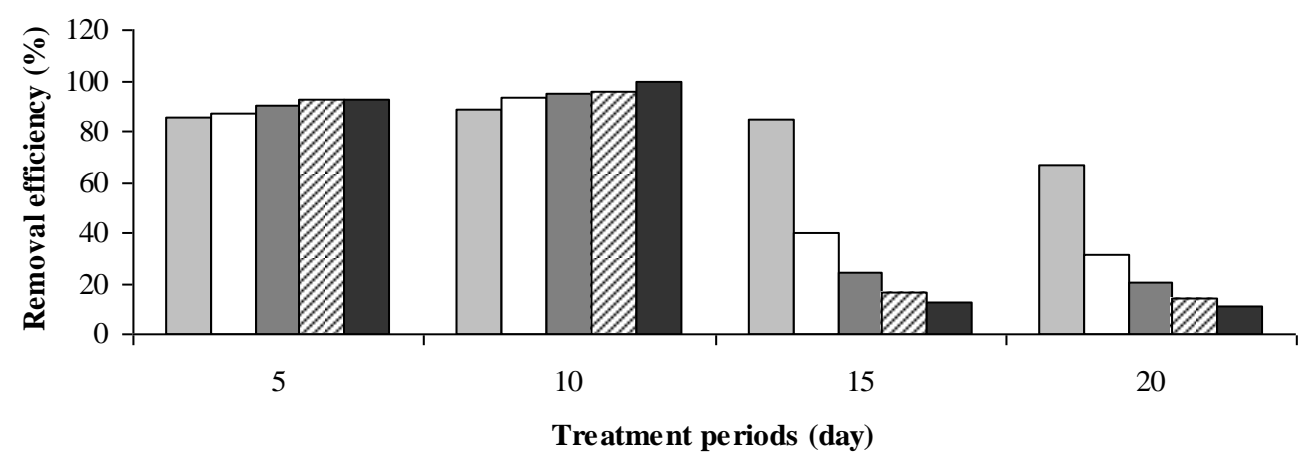

Fig. (5): Effect of pH 5 and $25 \mu \mathrm{M}$ of EDTA on removal efficiency of $\mathrm{Cr}$ by $L$. minor after different treatment periods 


\subsection{Effect of the treatment on Nile tilapia growth \\ 3.8.1. Estimation of growth parameters}

The results of growth parameters of fish that exposed to the treated water for 30 days are shown in Table (3). At the end of exposure period, the average final weight and length were $(43.8 \pm 2.42 \mathrm{gm}$ and $32.9 \pm 1.74 \mathrm{~cm})$ respectively. Meanwhile; a specific growth rate (SGR) of fish was $1.2 \pm 0.01 \% /$ day after 30 days of exposure the same as control group. Overall, the exposed fish and control group had no mortality rate during the exposure period.

\subsubsection{Analysis of chromium accumulation in fish muscles}

Accumulation of $\mathrm{Cr}$ in fish muscles was measured at the end of the exposure period and compared with control group (Table 3). Fish that exposed to the treated water had no chromium in their muscles.

Table (3): Effect of the treated water by L. minor on Nile tilapia growth.

\begin{tabular}{|c|c|c|c|c|c|c|c|}
\hline $\begin{array}{c}\text { Exposure } \\
\text { period } \\
\text { (day) }\end{array}$ & Fish & $\begin{array}{c}\text { Average } \\
\text { initial } \\
\text { weight } \\
(\mathrm{gm})\end{array}$ & $\begin{array}{c}\text { Average } \\
\text { final } \\
\text { weight } \\
(\mathrm{gm})\end{array}$ & $\begin{array}{c}\text { Average } \\
\text { initial } \\
\text { length } \\
(\mathrm{cm})\end{array}$ & $\begin{array}{c}\text { Average } \\
\text { final } \\
\text { length } \\
(\mathrm{cm})\end{array}$ & $\begin{array}{c}\text { Specific } \\
\text { growth rate } \\
\text { (SGR) } \\
(\% / \text { day })\end{array}$ & $\begin{array}{c}\text { Accumulation of } \\
\text { Cr in fish muscles } \\
\left(\mu \mathrm{g} \mathrm{g} \mathrm{g}^{-1} \text { dry wt }\right)\end{array}$ \\
\hline \multirow{3}{*}{30} & Control & $30.4 \pm 1.60$ & $43.6 \pm 2.30$ & $21.4 \pm 1.0$ & $32.7 \pm 1.71$ & $1.2 \pm 0.01$ & $\mathrm{ND}$ \\
\cline { 2 - 8 } & Exposed & $30.6 \pm 1.63$ & $43.8 \pm 2.42$ & $21.8 \pm 1.0$ & $32.9 \pm 1.74$ & $1.2 \pm 0.01$ & $\mathrm{ND}$ \\
\hline
\end{tabular}

Data are presented as mean of three samples \pm S.D, ND refers to non determined.

\section{DISCUSSION}

In recent years much attention has been given on wastewater treatment with the help of aquaculture (growth of aquatic plants having economic values) and recycling of treated water. The green plants degrade, assimilate, metabolize, or detoxify inorganic and organic pollutants from the environment or render them harmless. L. minor has been commonly used as a test organism in ecotoxicological and environmental studies (Khellaf and Zerdaoui, 2010) due to its high sensitivity to various chemicals, small size, rapid vegetative reproduction and easy handling in laboratory conditions. Chandra and Kulshreshtha (2004) reported duckweeds to have greater tolerance to Cr relative to other aquatic plants. Compared to most other aquatic plants, L. minor is less sensitive to low temperatures, very high nutrient levels, $\mathrm{pH}$ fluctuations, pests and diseases (Irfana et al., 2017). Goswami and Majumdar (2015) reported a significant reduction in specific growth rate of $L$. minor with increase in $\mathrm{Cr}(\mathrm{VI})$ concentration in ambient solution. According to Thayaparan et al. (2015), at the end of the experiment period (after 7 days) $\mathrm{Cr}(\mathrm{VI})$ caused a distinct limitation of Lemna's growth compared to the control. In this study, we investigated the accumulation of $\mathrm{Cr}$ in L. mionr under the effect of $\mathrm{pH}$ and EDTA variation and assessed the treatment impact on Nile tilapia growth. The parameters that monitored during this study were fresh and dry weights of L. minor, accumulation of $\mathrm{Cr}$ and BCF; as well as accumulation of $\mathrm{Cr}$ in Nile tilapia muscles. Both chromium concentration and $\mathrm{pH}$ directly affect the growth of $L$. minor and the data in this study emphasized that the toxic effects of $\mathrm{Cr}$ on L. minor is dependent on $\mathrm{pH}$. The selection of $\mathrm{pH}$ range was done on the basis of the survival potential of duckweed. 
Our results indicated that fresh and dry weights were positively affected by $\mathrm{pH} 5>$ $\mathrm{pH} 6>\mathrm{pH} 7>\mathrm{pH} 8>\mathrm{pH} 9$ during all the treatment periods. A similar observation has been reported in different studies that found duckweed growth declines with increase in alkaline pH (Kumar et al., 2015). According to Sekomo et al. (2012), the pH range of 4.5-7.5 was reported to be best suited range for the growth of duckweed species. Some characteristics e.g. L. minor can grow well in $\mathrm{pH}$ from 6 to 9 while the lowest value of $\mathrm{pH}$ it can tolerate in between $\mathrm{pH}$ 5-6 make it a suitable plant for phytoremediation (Chaudhary and Sharma, 2014). The chemical nature of the metals ion; strength and $\mathrm{pH}$ tends to be a master variable in accumulation process (Nwabunike, 2016). In acidic conditions, hydrogen ions occupy many of the negatively charged surfaces and little space is left to bind heavy metals, hence more heavy metals remain in the soluble phase. The present study appeared that the highest value of $\mathrm{Cr}$ accumulation was recorded with $\mathrm{pH} 5$; as well as accumulation of $\mathrm{Cr}$ in $L$. minor increased with increasing $\mathrm{Cr}$ concentration in nutrient solution followed by other $\mathrm{pH}(6,7,8$ and 9) during all the treatment periods. These results agreed with that reported by Rashmi and Surindra (2015), the uptake yield of $\mathrm{Pb}$ was the maximum in $5 \mathrm{mg} / \mathrm{L}$ set-up with $5 \mathrm{pH}$ followed by other set-ups. The uptake yield in set-ups was directly related to the metal loads and $\mathrm{pH}$ in culture medium. The effects of EDTA and other chelators on the uptake and toxicity of metals in aquatic biota have been investigated by numerous researchers (Borgrnann et al., 1991). Several studies suggest that the toxicity of different metals can also be mitigated by EDTA binding (Postma et al., 2000).

Overall, the results of the second experiment found that fresh and dry weights with $\mathrm{pH} 5$ and $25 \mu \mathrm{M}$ of EDTA have significantly increased after 10 days of treatment. Chelators are an essential component of a complete nutrient medium and should be included when measuring metal toxicity in aquatic plants, since L. trisulca grown without EDTA had low multiplication rates and appeared stunted and chlorotic (David and Jennifer, 1992). L. minor had the capacity to accumulate large quantities of $\mathrm{Cr}$ in solutions containing different concentrations of EDTA $(25,50,75$ and $100 \mu \mathrm{M})$. On the other hand, Kwan and Smith (1991), found that increasing the EDTA concentration from 6.8 to $50 \mathrm{pM}$ completely inhibited the Cd uptake in L. minor. Bioconcentration factor $(\mathrm{BCF})$ is an indicator of the metal accumulation ability of plants in respect of metal concentration in the medium and allows for a comparison of the results (Mountouris et al., 2002). In the current study, BCF value for Cr by L. minor was high at $10 \mathrm{mg} \mathrm{L}^{-1}$ with $\mathrm{pH} 5$ and $25 \mu \mathrm{M}$ of EDTA after 10 days of treatment as the best combinations for the optimum removal. On the basis of obtained results, L. minor can be considered as a hyperaccumulator for $\mathrm{Cr}$ under given conditions. In general, when the metal concentration in the feed solution increases, the amount of metal accumulating in plant increases, whereas, the BCF value decreases (Lu et al., 2004).

The highest removal efficiency of $\mathrm{Cr}$ by L. minor was $99.26 \%$ at $10 \mathrm{mg} \mathrm{L}^{-1}$ with $\mathrm{pH} 5$ and $25 \mu \mathrm{M}$ of EDTA after 10 days of treatment. Chromium amount decreased by $99.26 \%$ in nutrient solution and subsequently this element exhibited an increasing concentration in the plant fronds. The results of $\mathrm{Cr}$ removal are in accordance with a study which conducted by Abdallah (2012) found that L. gibba is a potential candidate in removing $\mathrm{Cr}$ and $\mathrm{Pb}$ about $95 \%$ and $84 \%$, respectively after 12 days of incubation. Also, Leela et al. (2012) stated that the maximum removal by L. mionr was found to be $99.99 \%$ for $\mathrm{Pb}$ at $\mathrm{pH} 5-6$ and $99.3 \%$ for $\mathrm{Ni}$ at $\mathrm{pH} 6$ after 28 days of exposure. Their study found 
that $\mathrm{Pb}$ removal was lowest $(95.94 \%)$ at $\mathrm{pH} 10$ after 7 days of exposure. In the same way the lowest $\mathrm{Ni}$ removal was achieved at $\mathrm{pH} 10$ after 7 days (73.78\%). The results of the present study indicated that the toxic effects of chromium on L. minor is dependent on $\mathrm{pH}$ and EDTA. Thus, $\mathrm{pH}$ and EDTA operated together on the removal of Cr. According to Campbell and Stokes (1985), the presence of chelators and $\mathrm{pH}$ influence the metal toxicities to aquatic organisms. The assessment of the treatment by L. minor under the effect of $\mathrm{pH}$ and EDTA using Nile tilapia as a test organism is very important. According to Gado and Midany (2003), fishes have been recognized as a good accumulator of organic and inorganic pollutants. Therefore, many international monitoring programs have been established in order to assess the quality of fish for human consumption and to monitor the health of the aquatic ecosystem (Meche et al., 2010).

Fish, in comparison with invertebrates, are more sensitive to many toxicants and are a convenient test subject for indication of ecosystem health (Zaki et al., 2014). Also, Fishes are considered to be most significant biomonitors in aquatic systems for the estimation of metal pollution level (Authman, 2008). However, fish are relatively situated at the top of the aquatic food chain; therefore, they normally can accumulate heavy metals from food, water and sediments (Zhao et al., 2012). Toxic effects of $\mathrm{Cr}$ in fish include: hematological, histological and morphological alterations, inhibition/reduction of growth, production of reactive oxygen species (ROS) and impaired immune function (Vera et al., 2011). According to Sfakianakis et al. (2015), poor treatment of the effluents can lead to the presence of $\mathrm{Cr}$ (VI) in the surrounding water bodies, where it is commonly found at potentially harmful levels to fish. Dupuy et al. (2014) reported that the fish health status in some polluted systems (estimated by the condition factor) indicated that the fish have a lower condition. Very low-levels of pollution may have no apparent impact on the fish itself, which would show no obvious signs of illness, but it may decrease the fecundity of fish populations, leading to a longterm decline and eventual extinction of this important natural resource (Ebrahimi and Taherianfard, 2011). In the third experiment, the fish that exposed to the treated water were healthy; as well as fish muscles had no $\mathrm{Cr}$ accumulation and this result due to the efficiency of L. minor in removal of $\mathrm{Cr}$ from polluted water under the effect of $\mathrm{pH}$ and EDTA. However, in polluted aquatic habitats the concentration of metals in fish muscles may exceed the permissible limits for human consumption and imply severe health threats (Elnabris et al., 2013).

\section{CONCLUSION}

Our results concluded that L. minor is a better candidate for treating high concentrations of chromium in polluted water under the effect of $\mathrm{pH}$ and EDTA. Fish that exposed to the treated water by L. minor were healthy and safe. Therefore, this method can be applied on the large scale for wastewater treatment. Finally, we recommend that the treatment of all kinds of wastewater, sewage and agricultural wastes must be conducted before discharge into the aquatic systems. Also, enforcement of all articles of laws and legislations regarding the protection of aquatic environment must be taken into considerations. 


\section{REFERENCES}

Abbas, H. H. and Ali, F. K. (2007). Study the effect of hexavalent chromium on some biochemical, cytotoxicological and histopathological aspects of the Oreochromis spp. Fish. Pak. J. Biol. Sci., 10: 3973-3982.

Abdallah, M. A. M. (2012). Phytoremediation of heavy metals from aqueous solutions by two aquatic macrophytes, Ceratophyllum demersum and Lemna gibba L, Environ. Technol., 33: 1609-1614.

Ahmed, M. K.; Kundu, G. K.; Al-Mamun, M. H.; Sarkar, S. K.; Akter, M. S. and Khan, M. S. (2013). Chromium (VI) induced acute toxicity and genotoxicity in freshwater stinging catfish, Heteropneustes fossilis. Ecotoxicol. Environ. Saf., 92: 64-70.

Authman, M. M. N. (2008). Oreochromis niloticus as a biomonitor of heavy metal pollution with emphasis on potential risk and relation to some biological aspects. Global Vet., 2(3): 104-109.

Borgrnann, U.; Norwood, W. R and Babirad, M. (1991). Relationship between Chronic toxicity and bioaccumulation of cadmium in Hyallela azteP.a. Can. J. Fish. Aquat. Sci., 48: 1055-1060.

Campbell, R. G. C and Stokes, P. M. (1985). Acidifacation and toxicity of metals to aquatic bioata. Can. J. Fish. Aquat.Sci., 42: 2034-3049.

Chandra, P. and Kulshreshtha, K. (2004). Chromium accumulation and toxicity in aquatic vascular plants. The Botanical Review 70(3): 313-327.

Chaudhary, E. and Sharma, P. (2014). Assessment of heavy metal removal efficiency of Lemna minor. International Journal of Innovative Research and Development, 3(6): 176-178.

David, B. H. and Jennifer, M. S. (1992). The Effect of EDTA on Cadmium and Zinc Uptake and Toxicity in Lemna trisulca L. Arch. Environ. Contam. Toxicol. 22: 313318.

Divya, S.; Richa, G. and Archana, T. (2012). Potential of duckweed (Lemna minor) for removal of lead from wastewater by phytoremediation. Journal of Pharmacy Research, 5(3): 1578-1582.

Duman, F.; Leblebici, Z. and Aksoy, A. (2009). Growth and bioaccumulation characteristics of watercress (Nasturtium officinale R. BR.) exposed to cadmium, cobalt and chromium. Chemical speciation and bioavailability, 21: 257-265.

Dupuy, C.; Galland, C.; Pichereau, V.; Sanchez, W. and Riso, R. (2014). Assessment of the European flounder responses to chemical stress in the English Channel, considering biomarkers and life history traits. Mar. Pollut. Bull.

Ebrahimi, M. and Taherianfard, M. (2011). The effects of heavy metals exposure on reproductive systems of cyprinid fish from Kor River. Iran J. Fish Sci., 10: 13-24.

El- Berashi, N. M. Y. (2008). Impacts of Azolla in increasing rice production and reducing environmental pollution . In ph.D. Ain Shams Univ., 110-157.

Eliasson, L. (1978). Effects of nutrients and light on growth and root formation in Pisum sativum cuttings. Physiol. Plant., 43: 13-18.

Elnabris, K. J.; Muzyed, S. K. and El-Ashgar, N. M. (2013). Heavy metal concentrations in some commercially important fishes and their contribution to heavy metals 
exposure in Palestinian people of Gaza Strip (Palestine). J. Assoc. Arab Univ. Basic Appl. Sci., 13: 44-51.

Frank, A. (1984). Automatic wet ashing, association of official analytical chemists, 7:1-5. Gado, M. S. and Midany, S. A. (2003). Studies on some heavy metals pollutants in cultured Oreochromis niloticus fish at kafer EI-Sheikh Govvernorate. Kafer EISheikh. Veterinary Medicine Journal, 1: 83-95.

Goswami, C. and Majumdar, A. (2015). Potential of Lemna minor in Ni and Cr removal from aqueous solution. Pollution, 1(4): 373-385.

Grčman, H.; Velikonja, B. Š.; Vodnik, D.; Kos, B. and Leštan, D. (2001). EDTA enhanced heavy metal phytoextraction: metal accumulation, leaching and toxicity. Plant and Soil, 235: 105-114.

Hoagland, P. R. and Arnon, D. I. (1950). The water culture method for growing plants without soil. California, College of Agriculture, Agricultural Experiment Statio, 347: 1-32.

Hughes, J. S. (1991). The use of aquatic plant toxicity tests in biomonintoring programs. $18^{\text {th }}$ Aquatic Toxicity Workshop. Sept. 30-Oct. 3, Ottawa, Ontario.

Irfana, S.; Farooq, A. L. and Javeed, I. A. B. (2017). Evaluation of the efficiency of duckweed (L. minor L.) as a phytoremediation agent in wastewater treatment in Kashmir Himalayas. J. Bioremediat. Biodegrad., 8:1-4.

Jafari, N. and Akhavan, M. (2011). Effect of pH and heavy metals concentration on phytoaccumulation of zinc by three duckweeds species. American Eurasian J. Agric. and Environ. Sci., 10(1): 34-41.

Kara, Y. (2004). Bioaccumulation of copper from contaminated wastewater by using $L$. minor. B. Environ. Contam. Tox., 72: 467- 471.

Khattab, Y. A. (1996). Some studies of fish growth. Egypt: Zagazig University, Faculty of Agriculture, 184p. (Ph. D. Thesis).

Khellaf, N. and Zerdaoui, M. (2010). Growth response of the duckweed L. gibba L. to copper and nickel phytoaccumulation. Ecotoxicology, 19: 1363-1368.

Kumar, A.; Singh, N. and Raje, P. (2015). Biomass productivity studies on L. minor (L.). Proceedings of $12^{\text {th }}$ ISERD International Conference, Tokyo, Japan, $26^{\text {th }}$ Sept., 2627.

Kurniawan, T. A.; Chan, G. Y. S.; Lo, W. H. and Babel, S. (2006). Physicochemical treatment techniques for wastewater laden with heavy metals. Chem. Eng. J., 118: 83-98.

Kwan, K. H. M. and Smith, S. (1991). Some aspects of the kinetics of cadmium and thallium uptake by fronds of Lemna minor L. New Phytol., 117: 91-102.

Landolt, E. and Kandeler, R. (1987). Biosystematic investigations in the family of duckweeds (Lemnaceae). The family of Lemnaceae-a monographic study, 2(6), 638.

Leela, K.; Kasturi, G. and Satyawati, S. (2012). Role of pH in the accumulation of lead and nickel by common duckweed (Lemna minor). International Journal of Bioassays, 1(12), 191-195.

Lu, X.; Kruatrachue, M.; Pokethiyook, P. and Homyok, K. (2004). Removal of cadmium and zinc by water hayacinth, Eichhornia crassipes. Science Asia, 30: 93-103. 
Meche, A.; Martins, M. C.; Lofrano, B. E. S. N.; Hardaway, C. J.; Merchant, M. and Verdade, L. (2010). Determination of heavy metals by inductively coupled plasmaoptical emission spectrometry in fish from the Piracicaba River in Southern Brazil. Microchem. J., 94: 171-174.

Mountouris, A.; Voutsas, E. and Tassios, D. (2002). Bioconcentration of heavy metals in aquatic environments: the importance of bioavailability. Mar. Pollut. Bull., 44: 1136-1141.

Nwabunike, M. O. (2016). The effects of bioaccumulation of heavy metals on fish fin over two years. J. Fisheries Livest. Prod., 4(2): 1-7.

Olaifa, F. G.; Olaifa, A. K. and Onwude, T. E. (2004). Lethal and sublethal effects of copper to the African Cat fish (Clarias gariepnus). Afr. J. Biomed. Res., 7: 65-70.

Oliveira, H. (2012). Chromium as an environmental pollutant: insights on induced plant toxicity. J. Bot., 1-8.

Perumal, S.; Alagappan, C.; Kaliyaperumal, S. G.; Pachikkaran, U. and Logalakshmanan, B. (2010). Chromium stress in paddy: (i) Nutrient status of paddy under chromium stress; (ii) Phytoremediation of chromium by aquatic and terrestrial weeds. C. R. Biologies, 333: 597-607.

Postma, J. W. M.; Keltjens, W. G.; Nelemans, J. A. and Tintelen, V. W. (2000). Interaction of Al (-EDTA) with the plant root: plant growth and nutrient uptake. Plant Physiol. Biochem. Suppl., 38: 136-142.

Rashmi, V. and Surindra, S. (2015). Lead and cadmium removal from water using duckweed - Lemna gibba L.: Impact of $\mathrm{pH}$ and initial metal load. Alexandria Engineering Journal, 54: 1297-1304.

Sekomo, C. B.; Rousseau, D. P. L.; Saleh, S. A. and Lens, P. N. L. (2012). Heavy metal removal in duckweed and algae ponds as a polishing step for textile wastewater treatment, Ecol. Eng., 44: 102-110.

Sfakianakis, D. G.; Renieri, E.; Kentouri, M. and Tsatsakis, A. M. (2015). Effect of heavy metals on fish larvae deformities: A review. Enviro. Res., 137: 246-255.

Shanker, A. K.; Cervantes, C.; Loza-Tavera, H. and Avudainayagam, S. (2005). Chromium toxicity in plants. Environ. Int., 31: 739-753.

Svobodova, Z.; Celechovska, O.; Kolara, J.; Randak, T. and Zlabek, V. (2004). Assessment of metal contamination in the upper reaches of the Ticha Orlice River, Czech. J. Anim. Sci., 49: 458-464.

Tanhan, P.; Kruatrachue, M.; Pokethititiyook and Chaiyarat, R. (2007). Uptake and accumulation of cadmium, lead and zinc by Siam weed (Chromolaena odorata (L.), King and Robinson). Chemosphere, 68: 323-329.

Thayaparan, M.; Iqbal, S. S. and Iqbal, M. C. M. (2015). Phytoremediation potential of Lemna minor for removal of $\mathrm{Cr}(\mathrm{VI})$ in aqueous solution at the optimum nutrient strength. OUSL Journal, 9: 97-111.

Uysal, Y. and Taner, F. (2009). Effect of $\mathrm{pH}$, temperature and lead concentration on the bioremoval of lead from water using Lemna minor. Int. J. Phytoremed., 11:591-608.

Venier, P.; Gava, C.; Zordan, M.; Bianchi, V.; Levis, A. G.; DeFlora, S.; Bennicelli, C. and Camoirano, A. (1987). Interactions of chromium with nitrllotriacetic acid (NTA) in the induction of genetic effects in bacteria. Toxicol. Environ. Chem., 14: 201-218. 
Vera, C. J.; Soloneski, S. and Larramendy, M. L. (2011). Acute toxicity of chromium on Cnesterodon decemmaculatus (Pisces: Poeciliidae). Theoria, 20: 81-88.

Vinodhini, R. and Narayanan, M. (2008). Bioaccumulation of heavy metals in organs of fresh water fish Cyprinus carpio (Common carp). Int. J. Environ. Sci. Tech., 5 (2), 179-182.

Wang, P. F.; Wang, C.; Wang, X. R.; Hou, J. and Zhang, S. H. (2008). The effect of hydrodynamics on nitrogen accumulation and physiological characteristics of Vallisneria spiraslis L. in eutrophicated water. African J. Biotech., 7: 2424-2443.

Zaki, M. S.; Authman, M. M. N.; Hammam, A. M. M. and Shalaby, S. I. (2014). Aquatic environmental pollution in the Egyptian countryside and its effect on fish production (Review). Life Sci. J., 11: 1024-1029.

Zhao, S.; Feng, C.; Quan, W.; Chen, X.; Niu, J. and Shen, Z. (2012). Role of living environments in the accumulation characteristics of heavy metals in fishes and crabs in the Yangtze River Estuary, China. Mar. Pollut. Bull., 64: 1163-1171.

\section{ARABIC SUMMARY}

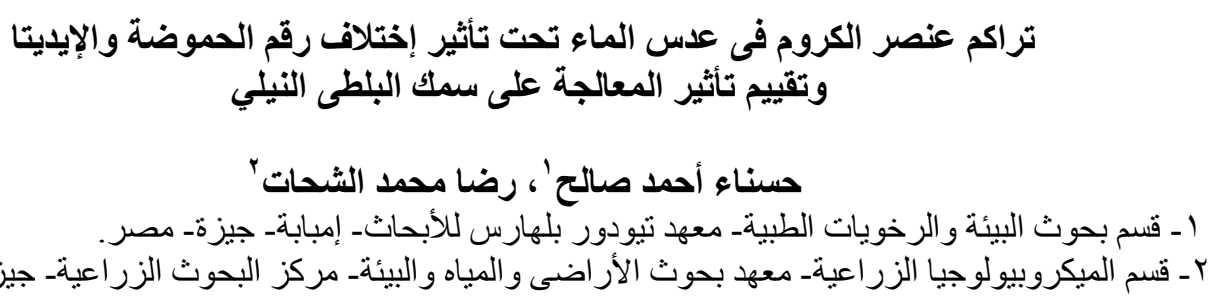

تلوث الماء بعنصر الكروم هو تهديد رئيسى للبيئة وصحة الإنسان. لذا هدف الدر اسـة الحالية هو تقييم كفاءة

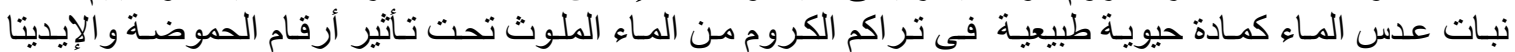

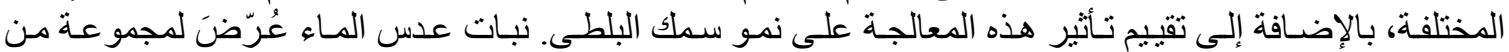

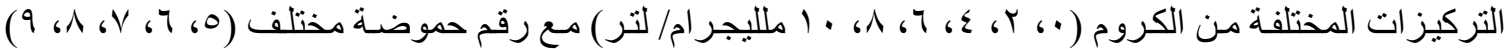

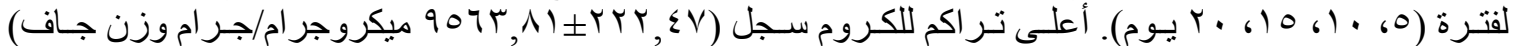

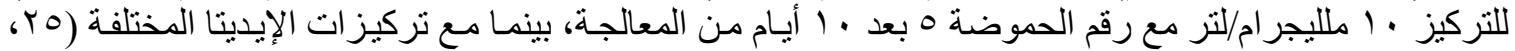

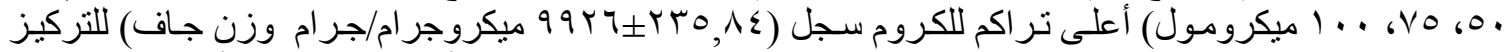

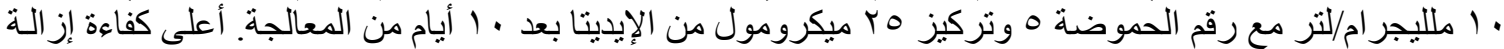

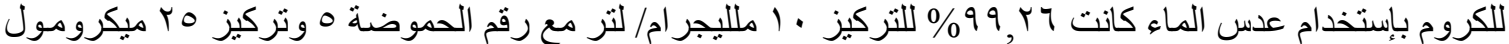

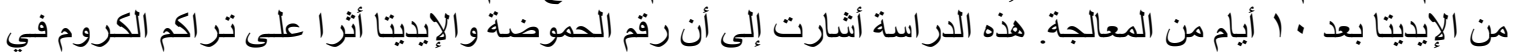

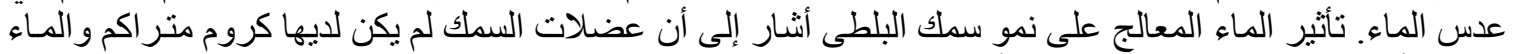

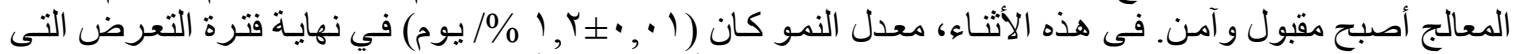

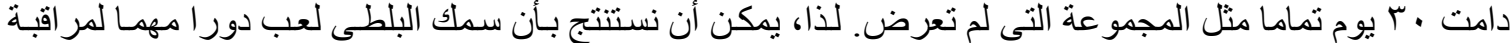

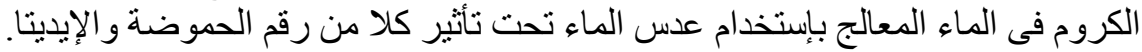

